\title{
Inclusion of Moringa Leaf Powder (Moringa oleifera) in Fodder for Feeding Japanese Quail (Coturnix coturnix japonica)
}

Author(s)
Castillo LRI'
Portillo LJJ"
León FJ'
Gutiérrez DR"I'
Angulo EMA'
Muy-Rangel MD'
Heredia JB'
' Laboratory of Antioxidants and Functional
Foods. Centro de Investigación en Alimen-
tación y Desarrollo, AC. Carretera a
Eldorado Km 5.5, Col Campo el Diez.
Culiacán, Sinaloa, México. CP 80110.
"Poultry Unit. Veterinary Medicine and
Zootechnics School. Universidad Autónoma
de Sinaloa. Blvd. San Ángel 3886, Fracc.
San Benito, Culiacán, Sinaloa, México.CP
80260.
"I Department of Biotechnology. Chemical-
Biology Sciences School. Universidad
Autónoma de Sinaloa. Blvd. de las Américas
y Josefa Ortiz de Domínguez S/N. Ciudad
Universitaria, Culiacán, Sinaloa, México. CP.
80013

\section{-Mail Address}

Corresponding author e-mail address J. Basilio Heredia

Laboratory of Antioxidants and Functional Foods. Centro de Investigación en Alimentación y Desarrollo, AC. Carretera a Eldorado Km 5.5 Col. Campo El Diez, Culiacán, Sinaloa, México. CP 80110 Tel: $\quad$ +52 (667)760-5536 Ext: 249 Email: jbheredia@ciad.mx

\section{-Keywords}

AGP, antioxidant, Coturnix, Moringa oleifera, phenolic.

\section{ABSTRACT}

This research evaluated the nutritional, nutraceutical, antimicrobial, as well as the growing promoter effect of Moringa oleifera (MOR) leaves flour in fodders for fattening Japanese quails. The antimicrobial activity was measured using the method of Kirby-Bauer. A completely random design with $4 \times 2$ factorial arrangement was used, fodders included $0,7,14$, and $21 \%$ of MOR, with and without Virginiamycin (100 ppm), during $35 \mathrm{~d}$ of fattening, 480 one-day old unsexed quails were used, each treatment had 5 replicates with 12 quails/cage. MOR inhibited the growth of bacteria gram (+) and gram (-). The inclusion of $\mathrm{MOR}$ in the period from 1 to $14 \mathrm{~d}$ inhibited the weight gain $(p<0.001)$, increased feed conversion $(p<0.001)$, without affecting the feed intake; however, in the period of 15 to $35 \mathrm{~d}$ MOR did not affect weight gain and the feed intake; the hematological and biochemical profile were within the normal range for quails. The inclusion of MOR decreased $(p \leq 0.001)$ cholesterol and triglycerides concentrations. Levels of aspartate aminotransferase (AST), alanine transferase (ALT), and creatinine decreased $(p \leq 0.001)$ when the amount of substitution of MOR was $21 \%$. The carcass weight and its yield with MOR up to $14 \%$ were similar $(p<0.001)$. The results of this experiment showed that flour from leaves of Moringa oleifera is a viable alternative to be included up to $14 \%$ in commercial diets of birds offering an option for AGP replacement without compromising the health of the animal and therefore its productivity.

\section{INTRODUCTION}

Food additives as antimicrobials or antibiotics growth promoters (AGP) play an essential role in the economic development of modern poultry production, which yields into benefits for producers and consumers of animal products (Brizuela et al., 2009; Dibner \& Richards, 2005). Additives are used in animal feed with three fundamental aims: to improve features in raw materials and fodders or animal products; to prevent diseases, and to increase the efficiency of animal production. However, due to the risk that AGP create cross-resistance with antibiotics used in human medicine and by the presence of these compounds in animal products, its use has been drastically reduced and prohibited in some cases for the formulation of fodders animal breeding (Gauthier et al., 2011). However, some researchers have suggested that the removal of these substances may cause an increase in the incidence of microbial infections (diarrhea, intestinal necrotic enteritis, and coccidiosis) (Ramírez et al., 2013). Thus, there's been the need of finding alternatives to the use of growth promoting antibiotics (Gauthier et al., 2011). Among these alternatives, the most used are the probiotics, prebiotics, enzymes, essential oils, herbs, spices, and vegetable extracts (Brizuela et al., 2009; Ayasan, 2013). In this sense, 
Castillo LR, Portillo UJ, León FJ, Gutiérrez DR, Angulo EMA, Muy-Rangel MD, Heredia JB
Inclusion of Moringa Leaf Powder (Moringa oleifera) in Fodder for Feeding Japanese Quail (Coturnix coturnix japonica) there are reports that extracts from leaves of Moringa oleifera (Moringa) possess antimicrobial activity on Gram positive and Gram negative bacteria (Devendra et al., 2011). In addition, the leaves have nutritional and nutraceutical properties (Makkar \& Becker, 1996), since they are characterized by their high content of proteins, vitamins and minerals, and low levels of anti-nutritional substances. Because of the above, they are traditionally used in Asia and Africa in animal feed (Makkar \& Becker, 1996; Singh et al., 2009; Fahey, 2005; Ayasan, 2015). On the other hand, the content of total phenols (105.04 mg Equivalent Acid Gallic (EAG)/g) and its antioxidant capacity (85.77\%) of methanolic extracts of Moringa leaves show their antioxidants properties (Singh et al., 2009). Therefore, the objective of this study is to determine the effect of the consumption of feed supplemented with Moringa leaves (Moringa oleifera) on the physiological state of Japanese quail (Coturnix coturnix japonica), according to its antimicrobial, nutritional and phytogenic features.

\section{MATERIALS AND METHODS}

\section{Materials and Chemical Analysis}

Plant Material. Mature leaves of Moringa oleifera (Moringa) were collected during the month of March 2015 from a crop located in the town of "La Campana", Culiacán, Sinaloa, Mexico ( $25^{\circ} 0^{\prime} 57^{\prime \prime} \mathrm{N}, 107^{\circ} 35^{\prime}$ $17^{\prime \prime} \mathrm{W}$, at 120 meters above sea level). Material plant was washed with a solution of $150 \mathrm{ppm}$ of sodium hypochlorite, for its later drying in an electric oven at $55-60{ }^{\circ} \mathrm{C}$ during 6 to $8 \mathrm{~h}$ until a constant weight to determine its moisture. Finally, it was smashed through a fine mill to obtain a homogenous particle size Moringa leaf flour. White corn (Maize) and soybean (Soya) intended for human and animal food paste was purchased in a local marketing company. Before developing the experimental diets, broken, damaged by insects, and immature grains were pulled out from the white corn, as well as of impurities. It was subsequently processed with a Thomas-Wiley mill (model 4, Thomas Scientific, Swedesboro, NJ, USA) with two $\mathrm{mm}$ mesh. The nutrient content and energy were analyzed according to the recommendations of The Official Methods of the Official Analytical Chemists Association (AOAC, 2000): moisture (method 934.01), fat (EE, method 920.39), protein (CP, method 960.52), dietary fiber (DF, method 985.29), crude fiber (CF, 978.10 method), ashes (method 942.05) and total carbohydrate (TC) were determined by the method of difference of $[100-(C P+E E+$ Moisture + ash $)]$ in percentage. The content of metabolizing energy (ME) was calculated through the formula ME (Mcal/ $/ \mathrm{kg})=$ $3.75 \times \mathrm{CP}+8.09 \times \mathrm{EE}-6.95 \times \mathrm{CF}+3.94 \times \mathrm{TC}$ (Moir et al., 1980). The concentration of calcium (Ca) and phosphorus $(\mathrm{P})$ in Moringa, corn and soybeans were quantified in accordance with the official method of the AOAC \# 955.06 (2005). After an acid digestion of their ashes, the sample was filtered and diluted to $100 \mathrm{~mL}$ with deionized water, an atomic absorption spectrophotometer (AA system Serie200 and GTA120 of Agilent Technologies, USA) was used to read the absorbance for each mineral in specific wave lengths: $\mathrm{Ca}(422.7 \mathrm{~nm}), \mathrm{Na}(589.6 \mathrm{~nm}), \mathrm{K}(769.9 \mathrm{~nm}), \mathrm{Mg}$ $(285.2 \mathrm{~nm}), \mathrm{Mn}(279.5 \mathrm{~nm}), \mathrm{Fe}(248.3 \mathrm{~nm}), \mathrm{Cu}$ $(324.7 \mathrm{~nm})$ and $\mathrm{Zn}(213.9 \mathrm{~nm})$. A reference of known concentration standards calibration curve was used for each mineral. The concentration of each of the minerals is calculated in ppm for microelements and g/ $\mathrm{kg}$ for macro elements.

The amino acids profile was performed using the technique for the detection and quantification of amino acids by high-performance liquid chromatography (HPLC) according to Vázquez-Ortizet al. (1995), with minimal variations. These were determined in Moringa, corn, and soybean used to develop the experimental diets. To do so, the Varian liquid chromatography system was used (Palo Alto, CA), high resolution 9012 model, adapted with a fluorescent 9075 Varian detectors, a $10 \mu \mathrm{L}$ volume injector, a PDS RPC C18 $10 \mathrm{~cm} \times 4.6 \mathrm{~mm}, \mathrm{ID} 3 \mu \mathrm{m}, 100 \mathrm{~A}$ column; and for cysteine, a Phenomenex Gemini 5u C18 110A 150 x $4.6 \mathrm{~mm}$ ID 5 um column. Hydrolysis. Approximately, 3 $\mathrm{g}$ of sample were weighed and moisture was removed and degreased. Sample preparation: after the sample degreasing, $3 \mathrm{mg}$ of it were taken for those in which the protein content was lower than $40 \%$, and $1 \mathrm{mg}$ for those whose protein content was more than $40 \%$. The samples were placed in tubes for hydrolysis (Pierse 29560) and $3 \mathrm{~mL}$ of HCL 6M. Vacuum was applied for 3 min to later place the tubes in a dry toilet at $110^{\circ} \mathrm{C}$ for 12 hours. To remove the HCL6M and obtain the sample, this was put in rota-evaporation at a temperature of $65^{\circ} \mathrm{C}$ (Brinkmann Buchi RE 121), through 3 washes with distilled water by adding the same volume of $\mathrm{HCL}$ ( $3 \mathrm{~mL}$ ). Then samples were collected with a 0.2 sodium citrate buffer $\mathrm{pH} 2.2, \mathrm{~N}$. The samples were immediately labeled and tested or stored at $0{ }^{\circ} \mathrm{C}$. Derivatization. An aliquot of $100 \mu \mathrm{L}$ of the hydrolysate was taken and added with $40 \mu \mathrm{L}$ of internal standard $2.5 \mu \mathrm{mol} / \mathrm{mL}$, this was diluted to $1 \mathrm{~mL}$ with sodium citrate buffer $\mathrm{pH}$ 2.2. $250 \mu \mathrm{L}$ of the dilution and $250 \mu \mathrm{L}$ of Ortho- 
Castillo LR, Portillo UJ, León FJ, Gutiérrez DR, Angulo EMA, Muy-Rangel MD, Heredia JB
Inclusion of Moringa Leaf Powder (Moringa oleifera) in Fodder for Feeding Japanese Quail (Coturnix coturnix japonica) phthalaldehyde (OPA) solution were taken into a syringe for chromatography. The mixture of these two solutions lasts 2 min to immediately undergo a filter $(0.2 \mu \mathrm{m})$ separation. $10 \mu \mathrm{L}$ of the derivative were taken and injected into the chromatograph Oxidation. For the determination of cysteine as cystic acid, the samples were subjected to a prior oxidation to the hydrolysis. The oxidation consisted in the use of performic acid $(90 \%)$ and peroxide (30\%) as oxidizingagents (9:1 v/v). The oxidizing solution was prepared and maintained at room temperature for 1 hour; subsequently, it was submitted to a cold bathroom at a temperature of $4^{\circ} \mathrm{C}$ for $15 \mathrm{~min}$; then $1 \mathrm{~mL}$ of oxidizing solution was added to the tubes of hydrolysis with $1 \mathrm{mg}$ of sample previously weighed; these were then submitted to a dry bath at a temperature of $50^{\circ} \mathrm{C}$ during $15 \mathrm{~min}$. For the removal of the oxidant solution, a lyophilisation (Labconco Freezone 6 plus serial 051044488A number) with freeze-drying was applied. Then it was followed by a hydrolysis with $\mathrm{HCL} 6 \mathrm{~N}$ for 12 hours at $110^{\circ} \mathrm{C}$. $A$ mobile phase with solvent $A$ was used: methanol and the solvent $B$ : sodium acetate buffer $(0.1 \mathrm{M}, \mathrm{pH}$ 7.2), methanol and tetrahydrofuran, which are used as organic modifiers (900:95:5 v/v/v), (Sigma Chemical Co.). The identification and quantification of amino acids were carried out by comparing the retention time of the control sample with the standard. To do so, the chromatography system was connected to a software (Barian Star Chromatography version 4.0) where the readings of the peaks in areas at wavelengths of $E X=$ $340 \mathrm{~nm}$ and $\mathrm{EM}=455 \mathrm{~nm}$ were reported.

The determination of the composition of fatty acids was analyzed by the methods of Folch et al. (1975) and the standard method of the AOAC 963.22 (1998) with some modifications. Previously, the following reagents were prepared: Folch reagent: $\mathrm{NaCl}$ $0.73 \%$. Weigh $7.3 \mathrm{~g}$ of $\mathrm{NaCl}$ and filling to $1 \mathrm{~L}$, and $\mathrm{NaCl} 0.58 \%$. Weight $5.8 \mathrm{~g}$ of $\mathrm{NaCl}$ and diluting to 1 liter. Removal of fat. Firstly, $10 \mathrm{~g}$ of the sample were weighed and placed in an Erlenmeyer flask of $250 \mathrm{~mL}$, mixed with $60 \mathrm{~mL}$ of the reagent of Folch (1 volume of methanol plus 2 volumes of chloroform), and finally homogenized. Subsequently, it was vacuumed with a Buchner funnel, the residue was mixed with $50 \mathrm{~mL}$ of the Folch reagent and homogenized again. It was vacuum filtered again. The residue was washed with $50 \mathrm{~mL}$ of Folch reagent, the flask cleaned, and vacuum filtered once more. The filtrates $(60+50+50 \mathrm{~mL})$ were mixed in a separating funnel and added with 40 $\mathrm{mL}$ of sodium chloride $0.73 \%$, stirred vigorously, and left decanting overnight. The next morning, the lower phase (organic) (F1) was decanted and filtered through anhydrous sodium sulfate. The filtering was recovered in a flat bottom around flask. The upper phase (F2) was washed with $50 \mathrm{~mL}$ of a mixture of $20 \% \mathrm{NaCl}(0.58 \%)$ and $80 \%$ of Folch reagent, stirred up, and left to rest for 2 hours, then decanted and filtered on anhydrous sodium sulfate getting F3. F1 and F3 were mixed, dry evaporated in the rota-evaporator. Methylation: After evaporating the chloroform, sodium hydroxide $0.5 \mathrm{~N}$ in methanol and 3 glass pearls were added. The flask was connected to a Rosario refrigerant and subjected to reflux for 10 minutes. After, through the top of the condenser boron trifluoride $\left(\mathrm{BF}_{3}\right)$ was added and refluxed for another 5 minutes, then $4 \mathrm{~mL}$ of heptane were added and refluxed for 2 minutes. The ball flask was removed from the heat and its content added to a test tube. Saturated $\mathrm{NaCl}$ was added and gently shaken until its milky white color changed. Subsequently, a piece of sodium sulphate was added to separate the fatty acids. The top of the mixture was taken out and filtered by a Pasteur pipette previously packed with glass fiber, and the filtering was recovered in a $2 \mathrm{~mL}$ vial. The vial was saved in a nitrogen atmosphere and was subsequently placed in the freezer. $1 \mu \mathrm{L}$ of the sample was injected into a gas chromatograph. The equipment used was a gas chromatograph (Varian (P-3800, USA) with a flame ionization detector (FID) equipped with a column Omega wax $32030 \mathrm{~m} \times 0.32$ $\mathrm{mm} \mathrm{ID}, 0.25 \mathrm{~mm}$ (Supelco, USA). Helium was used as the carrier gas at a flow rate of $3 \mathrm{~mL} / \mathrm{min}$. The oven temperature was maintained at $140^{\circ} \mathrm{C}$ for $5 \mathrm{~min}$, preset at a maximum temperature of $240^{\circ} \mathrm{C}$ at a speed of $4^{\circ} \mathrm{C}$ during $1.5 \mathrm{~min}$. Both the temperature of the injector and detector were set at $260^{\circ} \mathrm{C}$. For the identification and quantification of fatty acids, the retention times of the sample were compared with those of a standard mixture that consists of 37 fatty acid methyl esters (Supelco, Bellefonte, USA). The results were expressed in percentage of fatty acid contained in the sample.

Antimicrobial activity. Antimicrobial activity was evaluated by the paper diffusion method described by Prabuseenivasan et al. (2006) with modifications. Microorganisms used: Escherichia coli ATCC-25922, Staphylococcus aureus ATCC-25923, Salmonella typhimurium ATCC-14028, Candida albicans LMicM-7, Pseudomonas aeruginosa ATCC-27853 and Listeria monocytogenes ATCC-07644. A bacterial suspension was prepared, two or three previously selected colonies isolated and placed into tubes containing $108 \mathrm{~mL}$ of sterile solution to $0.87 \%$. Proceeded to adjust the suspension to a concentration of $10 \mathrm{CFU} /$ 
$\mathrm{mL}$ of each bacterial suspension samples with a sterile swab was taken, was rotated against the wall of the tube to remove excess inoculum and spread Moringa oleifera were diluted with $10 \%$ dimethylsulphoxide (DMSO) containing $0.5 \%$ Tween $80(\mathrm{v} / \mathrm{v})$ and sterilized by filtration through a membranous filter of $0.45 \mu \mathrm{m}$. The dilutions of the methanol extracts were 1: 1 (6.6 $\mathrm{mg} / \mathrm{disc}), 1: 5$ (2.6 mg/disc) and 1:10 (1.3 mg/disc), and $5 \mu \mathrm{L}$ of each dilution were added on sterile discs filter paper ( $5 \mathrm{~mm}$ diameter Whatman \# 1), they were placed in the center of the plates and incubated at $35^{\circ} \mathrm{C}$ for $24 \mathrm{~h}$. This was carried out in triplicate. 5 $\mu \mathrm{L}$ DMSO (solvent) was used as blank and positive control as ampicillin (Sigma-Aldrich CAS 49975) at the same concentrations as methanolic extracts. After the incubation time, and with the help of a calibrated digital Vernier (Digital LCD Groove Vernier Caliper, 150mm 6", Accuracy:+/-0.01MM +/-0.0005) caliper diameter halo of inhibition of bacterial growth for each disk was measured in $\mathrm{mm}$. The results reported were based on the proposal by scale Ponce et al. (2003) is not sensitive, if the total diameter was less than 8.0 $\mathrm{mm}$; sensitive to 9-14 $\mathrm{mm}$; highly sensitive to $15-19$ $\mathrm{mm}$; and extremely sensitive to inhibition diameters greater than $20 \mathrm{~mm}$.

\section{Diets}

\section{Fodders formulation and preparation of diets.} Fodders were made according to the nutritional requirements for Japanese quails and the standard NCR (1994) guidelines of the Council of production for these organisms. Four corn-based with soybean paste diets with different substitutions of $0,7,14$, and $21 \%$ for Moringa flour with and without AGP (0-100 ppm of Virginiamycin, Eskalin, PB Animal Health of Mexico S. de R.L. de C.V). The rest of the diet's ingredients (white maize, soybean oil, sea salt, methionine, limestone, orthophosphate, vitamins for fattening and minerals) were mixed in equal amounts with the protein sources to meet the quails' requirements according to the starter and finisher stages (Table 1).

\section{Birds Housing}

Location and climate. The productive response test was performed in the Poultry Unit and in the Food Analysis Laboratory of the Veterinary Medicine and Zootechnics Faculty of the Autonomous University of Sinaloa, located in the city of Culiacán, Sinaloa, Mexico. The test was performed from February to March, with an average temperature and relative humidity of $30^{\circ} \mathrm{C}$ and $67 \%$, respectively.
Animals and management. The institutional ethics Committee for the care and use of experimental animals of the Veterinary Medicine and Zootechnics Faculty of the Autonomous University of Sinaloa approved the experimental protocol of this investigation, based on Official Mexican Norm NOM-062-ZOO-1999 Technical specifications for the production, care and use of laboratory animals. The feeding test lasted 35 days. 480 unsexed one-day-old quail chicks $(12.13 \pm 0.01 \mathrm{~g})$ were used. The chicks quail are distributed randomly in 40 (90 cm x $90 \mathrm{~cm} \times 60 \mathrm{~cm}$ high) metal cages placed over $60 \mathrm{~cm}$ from the floor (12 birds per cage). They were provided with heat $\left(35\right.$ to $38^{\circ} \mathrm{C}$ ) using incandescent light bulbs during the first three days; from 32 to $35^{\circ} \mathrm{C}$ until the seventh day. On the second week temperature was reduced at a rate of $5^{\circ} \mathrm{C}$ (Lucotte, 1990). To ensure that birds had a suitable environment blue towel bed 75147 (Scott, Kimberly-Clark, USA) was placed on the cages floor. The walls and ceilings were covered with plastic sheeting during the first 10 days. These devices were gradually removed according to the increasing birds age. During the first three days a $25 \times 18 \times 2.5 \mathrm{~cm}$ dish type feeder and a 1/2 L glass barrel sprue were placed in each cage. On the fifth day, a $25 \times 17.5 \times$ $25 \mathrm{~cm}$ semi-automatic floor chute type feeder and a $1 \mathrm{~L}$ glass barrel sprue were placed. From the second week on, the chute type feeders were risen $2.5 \mathrm{~cm}$ by means of steel profiles, while preserving the same sprues. Within two weeks and a half, the feeders were raised $5 \mathrm{~cm}$ with steel profiles and a $2 \mathrm{~L}$ glass barrel sprue. To promote the animals' welfare, the cages were placed in a conventional booth, equipped with adjustable in height black plastic curtains, according to the room temperature, air currents, and sunlight. The food was served at 7:00 p.m. and the provided amount was recorded. At the end of the week, the food consumption per bird (offer less rejection of food between the number of animals) was estimated. During the course of the experiment weighings with digital scales (OhausMR, capacity of $2610 \mathrm{~g}$ and precision $0.1 \mathrm{~g}$ ) the food and the birds at the end of each period (14 $d$ and the $35 \mathrm{~d}$ ) were made to register the weight gain (final weight - initial weight), and feed conversion rate (feed intake between gained weight). Mortality was daily accounted and recorded. Dead or discarded birds were not replaced. To know the weight of the carcass and its performance percentage, all 35-day-old survived animals were sacrificed on the basis of the established procedures by the Official Mexican Norm NOM-033-ZOO-2014. They were processed according to the Genchev and Mihaylov protocol (2008) with slight modifications. 
Table 1 - Composition and calculated analysis of the basal diets.

\begin{tabular}{|c|c|c|c|c|c|c|c|c|}
\hline \multirow[b]{3}{*}{ Ingredient (\%) } & \multicolumn{4}{|c|}{ Diet of started (1 to $14 \mathrm{~d}$ ) } & \multicolumn{4}{|c|}{ Diet of finisher (15 to35 d) } \\
\hline & \multicolumn{4}{|c|}{ Moringa leaf powder } & \multicolumn{4}{|c|}{ Moringa leaf powder } \\
\hline & Control & $(7 \%)$ & $(14 \%)$ & $(21 \%)$ & Control & $(7 \%)$ & $(14 \%)$ & $(21 \%)$ \\
\hline Corn & 29.89 & 27.71 & 25.57 & 23.39 & 43.89 & 41.56 & 39.23 & 36.68 \\
\hline Soybean & 65.80 & 61.29 & 56.82 & 52.30 & 51.74 & 47.39 & 43.06 & 39.00 \\
\hline Moringa & - & 7.00 & 14.00 & 21.00 & - & 7.00 & 14.00 & 21.00 \\
\hline Salt & 0.35 & 0.35 & 0.35 & 0.35 & 0.35 & 0.35 & 0.35 & 0.30 \\
\hline DL-Methionine & 0.34 & 0.34 & 0.34 & 0.34 & 0.40 & 0.40 & 0.40 & 0.40 \\
\hline Limestone & 1.40 & 1.10 & 0.70 & 0.40 & 1.40 & 1.08 & 0.74 & 0.40 \\
\hline Mono-dicalcic phosphate & 1.10 & 1.10 & 1.10 & 1.10 & 1.10 & 1.10 & 1.10 & 1.10 \\
\hline Vitamins premix $^{1}$ & 0.30 & 0.30 & 0.30 & 0.30 & 0.30 & 0.30 & 0.30 & 0.30 \\
\hline Minerals premix ${ }^{2}$ & 0.06 & 0.06 & 0.06 & 0.06 & 0.06 & 0.06 & 0.06 & 0.06 \\
\hline Probiotic yeast (Saccharomyces cerevisiae) & 0.25 & 0.25 & 0.25 & 0.25 & 0.25 & 0.25 & 0.25 & 0.25 \\
\hline Adsorbent $^{3}$ & 0.30 & 0.30 & 0.30 & 0.30 & 0.30 & 0.30 & 0.30 & 0.30 \\
\hline Phytase $^{4}$ & 0.21 & 0.21 & 0.21 & 0.21 & 0.21 & 0.21 & 0.21 & 0.21 \\
\hline \multicolumn{9}{|l|}{ Calculated composition } \\
\hline Protein (CP), \% & 28.18 & 28.18 & 28.13 & 28.10 & 24.00 & 24.02 & 24.04 & 24.15 \\
\hline ME (kcal/kg) & 3111 & 3122 & 3135 & 3145 & 3148 & 3158 & 3169 & 3181 \\
\hline Lysine, \% & 1.99 & 1.94 & 1.90 & 1.86 & 1.60 & 1.56 & 1.52 & 1.49 \\
\hline Methionine, \% & 0.56 & 0.55 & 0.55 & 0.55 & 0.56 & 0.56 & 0.56 & 0.56 \\
\hline Cysteine, \% & 0.38 & 0.37 & 0.37 & 0.36 & 0.32 & 0.31 & 0.31 & 0.31 \\
\hline Threonine, \% & 1.07 & 1.07 & 1.06 & 1.06 & 0.89 & 0.88 & 0.88 & 0.88 \\
\hline Tryptophan, \% & 0.33 & 0.33 & 0.32 & 0.32 & 0.27 & 0.27 & 0.27 & 0.26 \\
\hline Calcium, \% & 0.95 & 0.97 & 0.94 & 0.95 & 0.91 & 0.92 & 0.91 & 0.91 \\
\hline Phosphorus, \% & 0.38 & 0.37 & 0.37 & 0.36 & 0.36 & 0.35 & 0.35 & 0.34 \\
\hline Crude fiber, \% & 2.49 & 2.89 & 3.29 & 3.69 & 2.36 & 2.76 & 3.16 & 3.56 \\
\hline Ether extract, \% & 2.47 & 3.13 & 3.78 & 4.44 & 2.69 & 3.35 & 4.00 & 4.65 \\
\hline Linoleic acid, \% & 1.28 & 1.24 & 1.21 & 1.18 & 1.35 & 1.32 & 1.29 & 1.25 \\
\hline Dry matter, \% & 88.31 & 88.68 & 89.06 & 89.43 & 88.42 & 88.79 & 89.17 & 89.54 \\
\hline \multicolumn{9}{|l|}{ Analyzed composition } \\
\hline Protein (CP), \% & 28.50 & 28.37 & 28.48 & 28.62 & 24.58 & 24.58 & 24.64 & 24.69 \\
\hline Ethereal extract, \% & 2.61 & 3.27 & 3.37 & 4.22 & 2.77 & 3.54 & 4.15 & 4.79 \\
\hline Dietetic fiber, \% & 19.84 & 20.12 & 21.00 & 22.08 & 17.01 & 17.30 & 18.41 & 19.50 \\
\hline Ash, \% & 7.54 & 6.82 & 8.22 & 8.35 & 7.10 & 7.75 & 8.80 & 8.92 \\
\hline Moisture, \% & 3.75 & 4.77 & 4.33 & 3.25 & 3.59 & 4.36 & 4.26 & 4.11 \\
\hline Carbohydrates, \% & 37.77 & 36.64 & 34.60 & 33.48 & 44.95 & 42.47 & 39.74 & 37.99 \\
\hline Crude fiber, \% & 2.79 & 2.67 & 3.05 & 3.21 & 2.63 & 2.53 & 3.05 & 3.21 \\
\hline
\end{tabular}

'Vitaminpremix provided the following per $\mathrm{kg}$ of diet: 12,500 IU(retinol); 4,480 IU(cholecalciferol); $30 \mathrm{IU}($ tocopherol acetate); $3 \mathrm{mg}$ Menadione sodium bisulfide; $1.5 \mathrm{mg}$ thiamin; 6 $\mathrm{mg}$ riboflavin; $3 \mathrm{mg}$ pyridoxine; $15 \mathrm{mg}$ cyanocobalamin; $1.5 \mathrm{mg}$ folic acid; $55 \mathrm{mg}$ niacin; $15 \mathrm{mg}$ Ca pantothenate; 180 mg biotin; $600 \mathrm{mg}$ choline; $120 \mathrm{mg}$ Banox (BHA + BHT).

${ }_{2}^{2}$ Mineral premix provided the following per kg of diet:75 mg Mn; $75 \mathrm{mg} \mathrm{Zn;} 75 \mathrm{mg} \mathrm{Fe;} 900 \mathrm{mg} \mathrm{Mo;} 750 \mu \mathrm{g} \mathrm{Co} ; 105 \mathrm{mg} \mathrm{Se}$.

${ }^{3}$ Aluminosilicate,Zeolex.

${ }^{4}$ Natuphos* 5000 GP Fitasa, Basf Mexicana, S.A. de C.V.

\section{Experimental Procedure}

Nutritional effect. To assess productive response, the following indicators were used: feed intake (FI), weight gain (WG), and feed conversion rate (FCR); to do so, a design with two crossed factors was used: AGP and Moringa through repeated measures in time, which were measured at the end of each phase. For live weight at slaughter (LWS), weight of the hot carcass (WHC), and carcass yield (CY) a design with two factors was used: AGP and Moringa, measured at day 35 . The birds were sacrificed with $3 \mathrm{~h}$ of fasting.
Phytogenics Effect. On day 35, male birds, identified according to the coloration of the chest and head (Woodard et al., 1973), were put on a diet for $8 \mathrm{~h}$, from the jugular vein of each decapitated quail, blood samples were extracted and put into test tubes with and without anticoagulant. Subsequently, blood chemistry analysis (serum cholesterol, triglycerides, uric acid, ALT, AST, creatinine, and glucose) was performed, and for hematic biometry (hematocrit, hemoglobin, leukocytes, protein, heterophile, and lymphocytes) birds were put on a diet for $12 \mathrm{~h}$. There was a design of a factor (diets), completely at hazard, taking as 
Castillo LR, Portillo UJ, León FJ, Muy-Rangel MD, Heredia JB Gutiérrez DR, Angulo EMA,

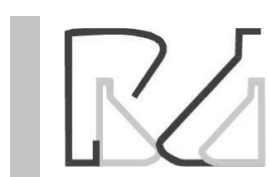

experimental unit quails selected at random from each cage for a total of 5 replicates per treatment.

\section{Statistical Analysis}

Data from the experiment was analyzed as a completely random $4 \times 2$ factorial arrangement design. Two nest factors: MOR: 0, 7, 14 and 21\%, and AGP: 0-100 $\mathrm{ppm}$. For the productive response, a crossed factor of the feeding periods was included: 1 to $14 \mathrm{~d}$ initiation and completion of 15 to $35 d$, the experimental unit was every cage (12 quails), and this was considered as a random effect. The main effects and interactions of the first and second order were tested. For hematologic variables the main effects and interaction of the first order interactions were assessed, the experimental unit was every sample of blood. For carcass data, the effect of sex was included in the analysis, as well as all the possible interactions, the unit of observation was each carcass. All the collected data was analyzed using the statistical package Minitab v. 17. The declaration of statistical difference was based on a value of $p \leq 0.05$, the Tukey multiple comparison test was used.

\section{RESULTS AND DISCUSSION}

\section{Productive Response}

The substitution of soybean meal by Moringa (MOR) flour strongly affected the weight, and therefore the weight gain in the period of initiation of 1-14 $d$, the MOR factor is statistically significant $(p<0.001)$. The more the inclusion of MOR increased at $0,7,14$, and $21 \%$ and soybean meal dropped by about $4 \%$ in the experimental diets, it was observed a progressive reduction in weight, which resulted in lower weight gain at 14 days compared with the control of $4.72 \%$, 8.76 , and $17.93 \%$, respectively. It was observed that increased inclusion of MOR resulted in lower weight gain, this effect is mainly due to MOR, since food consumption was not significantly different ( $p>0.05)$, although a statistical significance was observed in diets containing $\operatorname{AGP}(p<0.05)$. The conversion rate increased as the inclusion of MOR increased in the diet during the $14 \mathrm{~d}$ experimental period $(p<0.001)$. In 35-day-old quails, the replacement of the $0,7,14$ of MOR did not affect significantly the weight $(p>0.05)$, the weight gain was similar; however, there was a significant difference between the weight at $0 \%(235.70 \mathrm{~g})$ and $21 \%(218.26 \mathrm{~g})$ of replacement of MOR $(p<0.002)$, not showing significant difference for AGP $(p>0.05)$. Due to the previous effects, feed conversion increased significantly at 35 days of age $(p<0.01)$. Food intake was not affected by the replacement of MOR flour

Inclusion of Moringa Leaf Powder (Moringa oleifera) in Fodder for Feeding Japanese Quail (Coturnix coturnix japonica)

( $p>0.05)$, but it was by the presence of AGP in the diet. The highest weight gain was observed at 0,7 , and $14 \%$ of inclusion of MOR, and the lowest was obtained by the inclusion of $21 \%$ of MOR although the latter had greater weight recovery in the same period while diets with and without AGP were kept in intermediate weights, not presenting significant differences between them ( $p=0.080$ ) (Table 2). The fact that there is no significant difference in feed intake among the treatments with the inclusion of Moringa that affects the energy and nutrient contribution of diets, since the feed intake of any animal species is determined by nutrimental requirements, and an increase in feed intake is observed when the contribution of the diet is low in terms of nutritional quality and low dietary

Table 2 - Nutritional composition of the Moringa leafpowder.

\begin{tabular}{|c|c|}
\hline Item $^{1}$ & Value \\
\hline \multicolumn{2}{|l|}{ Proximal analysis (\%) } \\
\hline Protein $(C P)$ & 28.90 \\
\hline Fat (EE) & 12.63 \\
\hline Dietary fiber (DF) & 21.97 \\
\hline Ash & 9.54 \\
\hline Moisture & 6.27 \\
\hline Total carbohydrate (TC) & 21.00 \\
\hline Crude fiber (CF) & 8.49 \\
\hline \multicolumn{2}{|c|}{ Amino acids (\%, g AAS/100 g) } \\
\hline Aspartate & 2.18 \\
\hline Glutamate & 2.83 \\
\hline Threonine & 1.04 \\
\hline Tryptophan & 0.28 \\
\hline Serine & 1.13 \\
\hline Histidine & 0.84 \\
\hline Glycine & 1.32 \\
\hline Arginine & 1.32 \\
\hline Alanine & 1.17 \\
\hline Tyrosine & 0.74 \\
\hline Methionine & 0.23 \\
\hline Valine & 0.88 \\
\hline Phenylalanine & 1.22 \\
\hline Isoleucine & 0.61 \\
\hline Leucine & 1.95 \\
\hline Lysine & 1.43 \\
\hline Proline & 1.09 \\
\hline Cysteine & 0.31 \\
\hline \multicolumn{2}{|l|}{ Minerals (g/kg) } \\
\hline $\mathrm{Ca}$ & 21.51 \\
\hline$P$ & 0.62 \\
\hline \multicolumn{2}{|l|}{ Essential fatty acids (\%) } \\
\hline Oleic & 2.25 \\
\hline Linoleic & 65.26 \\
\hline Linolenic & 6.97 \\
\hline \multicolumn{2}{|l|}{ Energy } \\
\hline $\mathrm{ME}, \mathrm{Kcal} / \mathrm{kg}$ & 3485.15 \\
\hline
\end{tabular}


Castillo LR, Portillo UJ, León FJ,

Gutiérrez DR, Angulo EMA,

Muy-Rangel MD, Heredia JB
Inclusion of Moringa Leaf Powder (Moringa oleifera) in Fodder for Feeding Japanese Quail (Coturnix coturnix japonica) energy density (Aami-Azghadi et al., 2014). Diets with a high content of CF and DF remain longer in the gizzard, which reduce this indicator. The results differ from Ashong \& Brown, (2011), who stated that, when using diets with different levels of inclusion of Moringa leaves flour in White Leghorn chickens from 7 days up to 5 weeks; with substitution levels of Moringa flour at $0 \%$ (control group), 10\%, 20\% and 30\%, found significant differences in feed intake. Since as the percentage of inclusion increased, feed intake decreased significantly, the nutrient and energy intake increased, and therefore caused greater satiety in birds, although it could be due to the fiber effect discussed above and not by what they claim. In this respect, Aami-Azghadi et al. (2014) and Cruz et al. (2005) suggest that diets should contain protein and energy densities according to the stage of development of the birds. In the diets used in this study, the protein level was constant and the energy, raw fiber and dietary fiber increased with the greater inclusion of MOR (Table 1). It is possible that intestinal motility has increased due to the assimilation of protein and energy was lower than required, resulting in a higher rate of food transit (Jerry, 1996; Mateos et al., 2012). This was also associated with the immaturity of the digestive tract of the quail, resulting in a lower weight gain in the first period. According to the above, the Moringa factor was highly statistically significant in weight gain, as shown in Figure 2; the gain of weight in the period from 1 to $14 \mathrm{~d}$ decreased when the level of Moringa increased. This is also in line with the results of a study conducted by Olugbemi et

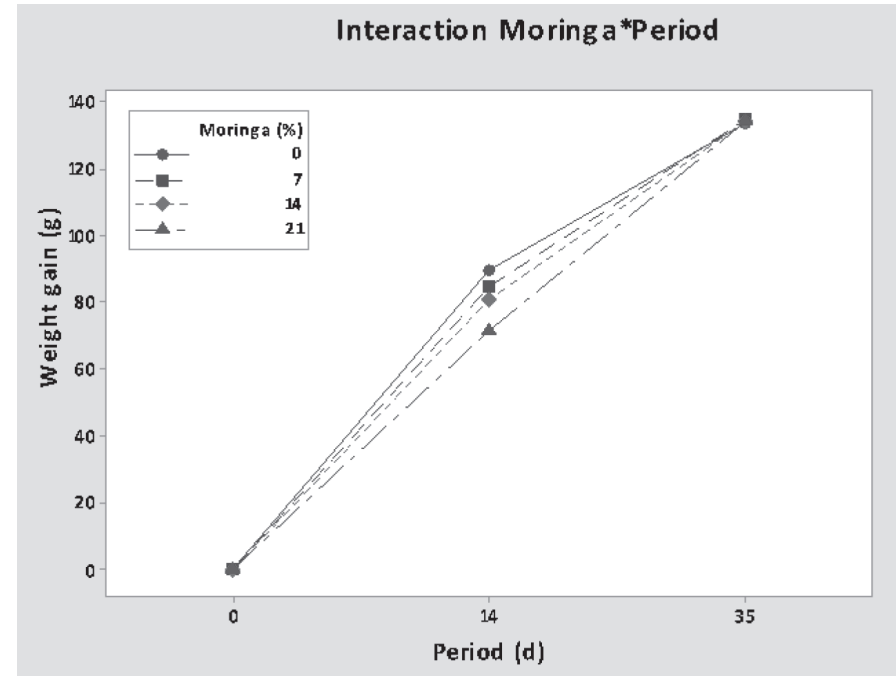

Figure 1 - Weight gain of quail from 0 to 35 days of age, sudmitted to different treatments.

Table 3 - Effect of inclusion of Moringa, with and without AGP by weight, weight gain, feed intake and feed conversion rate in Japanese quail from 1 to 35 days old.

\begin{tabular}{|c|c|c|c|c|c|c|c|c|c|c|c|c|c|}
\hline \multirow{2}{*}{ Ítem } & \multirow{2}{*}{ Level } & \multicolumn{3}{|c|}{ Weight (g) } & \multicolumn{3}{|c|}{ WG(g) } & \multicolumn{3}{|c|}{$\mathrm{Fl}(\mathrm{g})$} & \multicolumn{3}{|c|}{ FCR $(\mathrm{g} / \mathrm{g})$} \\
\hline & & $0 \mathrm{~d}$ & $14 \mathrm{~d}$ & $35 d$ & $0-14 d$ & $14-35 d$ & $0-35 d$ & $0-14 d$ & $14-35 d$ & $0-35 d$ & $0-14 d$ & $14-35 d$ & $0-35 d$ \\
\hline \multicolumn{14}{|l|}{ Main effect } \\
\hline \multirow{4}{*}{ MOR } & 0 & 12.13 & $101.94^{a}$ & $235.70^{a}$ & $89.81^{a}$ & 133.76 & $223.57^{a}$ & 163.43 & 624.5 & 789.40 & $1.82^{c}$ & 4.68 & $3.54^{b}$ \\
\hline & 7 & 12.20 & $97.12^{\mathrm{ab}}$ & $232.29^{a}$ & $84.92^{\mathrm{ab}}$ & 135.17 & $220.09^{a}$ & 163.26 & 615.8 & 779.10 & $1.93^{\mathrm{bc}}$ & 4.56 & $3.54^{b}$ \\
\hline & 14 & 12.16 & $93.00^{\mathrm{b}}$ & $227.51^{\mathrm{ab}}$ & $80.84^{b}$ & 134.51 & $215.35^{\mathrm{ab}}$ & 166.51 & 625.5 & 792.00 & $2.06^{b}$ & 4.67 & $3.68^{\mathrm{ab}}$ \\
\hline & 21 & 12.10 & $83.66^{c}$ & $218.26^{b}$ & $71.56^{c}$ & 134.60 & $206.16^{b}$ & 162.26 & 620.5 & 782.80 & $2.27^{\mathrm{a}}$ & 4.61 & $3.80^{\mathrm{a}}$ \\
\hline SEM $^{1}$ & & 0.16 & 1.61 & 2.54 & 1.56 & 2.04 & 2.52 & 4.56 & 11.50 & 14.10 & 0.05 & 0.10 & 0.06 \\
\hline \multirow{2}{*}{ AGP } & Without & 12.22 & 92.49 & 226.26 & 80.24 & 133.77 & 214.02 & $168.52^{\mathrm{a}}$ & 632.68 & $801.93^{a}$ & $2.12^{\mathrm{a}}$ & $4.73^{a}$ & $3.75^{a}$ \\
\hline & With & 12.05 & 95.37 & 230.62 & 83.32 & 135.25 & 218.57 & $159.21^{b}$ & 610.51 & $769.72^{b}$ & $1.93^{b}$ & $4.52^{b}$ & $3.53^{b}$ \\
\hline SEM $^{1}$ & & 0.11 & 1.14 & 1.80 & 1.10 & 2.04 & 1.78 & 3.23 & 8.10 & 9.99 & 0.03 & 0.07 & 0.04 \\
\hline \multicolumn{14}{|c|}{ Interaction effect } \\
\hline 0 & Without & 12.22 & 99.49 & 234.44 & 87.27 & 134.95 & 222.22 & 168.42 & 654.00 & 825.40 & 1.93 & 4.85 & 3.72 \\
\hline 0 & With & 12.04 & 104.39 & 236.96 & 92.35 & 132.57 & 224.92 & 158.44 & 595.00 & 753.50 & 1.71 & 4.50 & 3.35 \\
\hline 7 & Without & 12.23 & 95.75 & 228.00 & 83.52 & 132.25 & 215.77 & 164.97 & 606.90 & 771.90 & 1.98 & 4.60 & 3.58 \\
\hline 7 & With & 12.17 & 98.49 & 236.57 & 86.32 & 138.08 & 224.41 & 161.55 & 624.80 & 786.40 & 1.87 & 4.53 & 3.50 \\
\hline 14 & Without & 12.26 & 92.10 & 226.53 & 79.84 & 134.43 & 214.27 & 173.08 & 647.60 & 820.70 & 2.17 & 4.80 & 3.83 \\
\hline 14 & With & 12.06 & 93.89 & 228.49 & 81.83 & 134.60 & 216.43 & 159.95 & 603.40 & 763.30 & 1.95 & 4.51 & 3.53 \\
\hline 21 & Without & 12.27 & 82.61 & 216.07 & 70.34 & 133.46 & 203.80 & 167.63 & 622.20 & 789.80 & 2.39 & 4.66 & 3.87 \\
\hline 21 & With & 11.94 & 84.71 & 220.46 & 72.77 & 135.74 & 208.52 & 156.89 & 618.80 & 775.70 & 2.15 & 4.56 & 3.72 \\
\hline $\mathrm{SEM}^{2}$ & & 0.23 & 2.28 & 3.59 & 2.20 & 2.89 & 3.56 & 6.45 & 16.20 & 20.00 & 0.07 & 0.14 & 0.08 \\
\hline Source of va & tion & \multicolumn{12}{|c|}{$p$ value } \\
\hline MOR & & 0.978 & 0.001 & 0.001 & 0.001 & 0.970 & 0.001 & 0.921 & 0.930 & 0.911 & 0.001 & 0.832 & 0.006 \\
\hline AGP & & 0.233 & 0.083 & 0.096 & 0.057 & 0.476 & 0.080 & 0.050 & 0.062 & 0.029 & 0.001 & 0.045 & 0.001 \\
\hline$M O R^{*} A G P$ & & 0.949 & 0.903 & 0.791 & 0.898 & 0.545 & 0.797 & 0.890 & 0.850 & 0.138 & 0.786 & 0.679 & 0.244 \\
\hline
\end{tabular}

$a, b, c$ Different letters in column indicate significant differences between samples $(p \leq 0.05)$.

${ }^{1}$ Standard error of the means for MOR $(n=10)$ and AGP $(n=20)$.

${ }^{2}$ Standard error of the means for MOR and AGP levels interaction AGP $(n=5)$. 
Castillo LR, Portillo UJ, León FJ,

Gutiérrez DR, Angulo EMA,

Muy-Rangel MD, Heredia JB
Inclusion of Moringa Leaf Powder (Moringa oleifera) in Fodder for Feeding Japanese Quail (Coturnix coturnix japonica) al. (2010) when including Moringa up to 5\% in diets based on cassava in broilers. In addition, it coincides with a study reported by Gadzirayi et al. (2012), where they replaced soybean meal with Moringa (0\%, $25 \%, 50 \%, 75 \%$ and $100 \%$ ), and where the average weight of broilers was maintained until a replacement of $25 \%$ of Moringa. They attributed this effect to the high levels of fiber in diets. Results according to the literature that monogastric cannot use diets with a high content of crude fiber in an efficient way as previously discussed. There is another possibility that the digestive apparatus in quails could be passing by a period of adaptation to the CF and FD, as well as antioxidant and antibacterial components; this effect is progressive and not immediately as the AGP. The antioxidant and antimicrobial effects of Moringa oleifera have been mainly studied in vitro (Prakash et al. 2007; Saikia et al. 2011; Sankhalkar 2014; Adline et al. 2014; Ajayi \& Fadeyi, 2015). Its effects and mechanisms of action in vivo models are still being studied (Amer \& Khan, 2012; Okorondu et al. 2012). The analysis of variance for the feed conversion rate of Japanese quails showed statistically significant differences of Moringa and AGP. The feed conversion in the first period was due to the effect of the weight gain in the period of initiation. But for the completion of the experiment, feed conversion had no significant difference between is $0 \%$ at $14 \%$ (Table 3).

\section{Carcass Yield}

The weight gain resulted in significant differences $(p<0.001)$. Therefore, live weight at slaughter (LWS), weight of the hot carcass (WHC) and carcass yield (CY) also showed significant differences $(p<0.001)$, due to the main effect caused by the inclusion of MOR (Table 4). The yields obtained were close to $61 \%$, similar to those reported by Obregón (2012) and Aybar (2011).

\section{Blood Characteristics}

The hematological results of this investigation reflect that the inclusion of Moringa in diets did not contain substances that could alter some hematological parameters, since there only were significant differences in values regarding leukocytes, lymphocytes, ALT, and AST; in spite of this, they are within the normal range for Japanese quails (Table 5 and 6) (Woodard et al., 1973; Itoh et al., 1998; Uyanik et al., 2005; Asrani, 2006; Ayoola et al., 2015). Concerning hematocrit, heterophyle, and hemoglobin parameters, there are no significant differences between diets with MOR meaning that there wasn't any type of infection or inflammatory process in birds. In addition, Onibi et

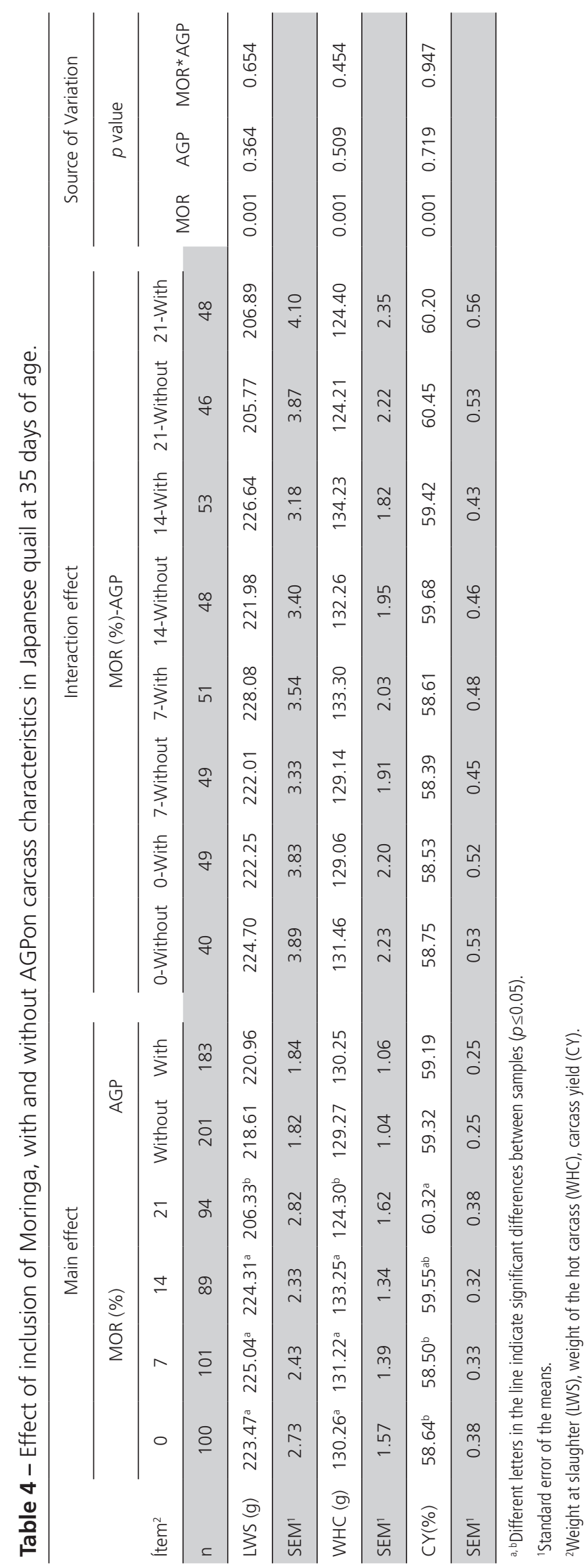


Table 5 - Results of the hematic biometry of Japanese quail maleswith diets 0, 7, 14 and 21\% Moringa, without and with AGP, to $35 \mathrm{~d}$.

\begin{tabular}{|c|c|c|c|c|c|c|c|c|}
\hline Ítem & Level & $\begin{array}{c}\text { Hematocrit } \\
31-41 \\
\% \\
\end{array}$ & $\begin{array}{c}\text { Hemoglobin } \\
12.9-14.5 \\
\mathrm{~g} / \mathrm{dL} \\
\end{array}$ & $\begin{array}{c}\text { Leukocytes } \\
14.7-30.7 \\
\mathrm{M} / \mathrm{mm} 3 \\
\end{array}$ & $\begin{array}{c}\text { Heterophil } \\
50-52 \\
\% \\
\end{array}$ & $\begin{array}{c}\text { Lymphocytes } \\
40-46 \\
\% \\
\end{array}$ & $\begin{array}{c}\text { Glucose } \\
93.60-141.50 \\
(\mathrm{mg} / \mathrm{dL})\end{array}$ & $\begin{array}{c}\text { Protein } \\
64-83 \\
\mathrm{~g} / \mathrm{L} \\
\end{array}$ \\
\hline \multicolumn{9}{|l|}{ Main effect } \\
\hline \multirow[t]{4}{*}{ MOR } & 0 & 40.60 & 12.55 & $23.04^{a}$ & 53.50 & 44.60 & 96.70 & 65.77 \\
\hline & 7 & 39.60 & 13.07 & $21.72^{a}$ & 50.90 & 43.90 & 98.40 & 64.45 \\
\hline & 14 & 39.10 & 12.93 & $19.63^{b}$ & 52.40 & 42.70 & 100.70 & 63.40 \\
\hline & 21 & 39.00 & 13.11 & $18.41^{b}$ & 53.60 & 42.80 & 101.60 & 62.80 \\
\hline SEM $^{1}$ & & 0.660 & 0.226 & 0.380 & 0.845 & 0.896 & 1.380 & 0.915 \\
\hline \multirow[t]{2}{*}{$A G P$} & Without & 39.95 & 12.80 & 20.81 & 52.30 & $45.35^{a}$ & 99.8 & 64.24 \\
\hline & With & 39.20 & 13.03 & 20.59 & 52.90 & $41.65^{b}$ & 98.9 & 63.97 \\
\hline SEM $^{1}$ & & 0.47 & 0.16 & 0.27 & 0.60 & 0.63 & 0.98 & 0.65 \\
\hline \multicolumn{9}{|l|}{ Interaction effect } \\
\hline 0 & Without & 40.80 & 12.02 & 23.16 & 54.80 & 48.00 & 95.40 & 65.74 \\
\hline 0 & With & 40.40 & 13.08 & 22.92 & 52.20 & 41.20 & 98.00 & 65.80 \\
\hline 7 & Without & 39.40 & 13.12 & 21.81 & 50.00 & 45.80 & 97.40 & 64.48 \\
\hline 7 & With & 39.80 & 12.03 & 21.62 & 51.80 & 42.00 & 99.40 & 64.42 \\
\hline 14 & Without & 39.60 & 12.93 & 19.70 & 51.60 & 44.40 & 102.60 & 63.76 \\
\hline 14 & With & 38.40 & 12.94 & 19.56 & 53.20 & 41.00 & 98.80 & 63.04 \\
\hline 21 & Without & 40.00 & 12.94 & 18.56 & 52.80 & 43.20 & 103.80 & 62.98 \\
\hline 21 & With & 38.20 & 13.09 & 18.26 & 54.4 & 42.4 & 99.4 & 62.62 \\
\hline $\mathrm{SEM}^{2}$ & & 0.93 & 0.32 & 0.54 & 1.19 & 1.27 & 1.96 & 1.29 \\
\hline Source of variation & \multicolumn{8}{|c|}{$p$ value } \\
\hline MOR & & 0.314 & 0.293 & 0.001 & 0.106 & 0.389 & 0.071 & 0.130 \\
\hline AGP & & 0.264 & 0.313 & 0.572 & 0.483 & 0.001 & 0.520 & 0.770 \\
\hline$M O R * A G P$ & & 0.667 & 0.231 & 0.999 & 0.209 & 0.153 & 0.168 & 0.991 \\
\hline
\end{tabular}

a,bDifferent letters in the line indicate significant differences between samples $(p \leq 0.05)$.

'Standard error of the means for MOR $(n=10)$ and AGP $(n=20)$.

${ }^{2}$ Standard error of the means for MOR and AGP levels interaction AGP $(n=5)$.

al. (2011) reported that the decrease of red blood cells is mainly associated with the low quality of food and protein deficiency suggesting that Moringa has good quality and does not affect the physiological development of birds. The replacement of MOR meal in diets suggests antimicrobial effect in diets (Devendra et al., 2011; Ndhlala et al., 2014) due to the only significant concentration of leukocytes observed $(p<0.001)$ having a greater concentration in the diet of $0 \%$ of MOR, values within the acceptable range for this variable. This can be supported with the results of the concentration of lymphocytes, since their lower concentration occurs in diets with AGP, fulfilling its antimicrobial function. The hematological variables are commonly altered by the influence of different dietary treatments (Aletor \& Edberongbe, 1992). With respect to the variables of kidney and liver failure, the inclusion of MOR in diets is significant for the case of $\operatorname{ALT}(p<0.00)$ and creatinine $(p<0.001)$. The higher this inclusion is, the lower these variables get, avoiding therefore the liver and kidney failure respectively by the presence of xenobiotics in the diets that could damage them. Regarding the AST, it was significant the presence of the AGP $(p<0.05)$ resulting in the increase of this variable from 221.75 to $223.45 \mathrm{u} / \mathrm{L}$. The use of Virginiamycin as AGP could result into renal damage since the Japanese quails can be sensitive to this antibiotic (Reece, 1988).

\section{Phytogenic Activity}

Quails' serum cholesterol concentration (Table 6) presented significant differences among the used diets $(p<0.05)$. When increasing the percentage of MOR in diets, cholesterol values tend to decrease; this can be due to the nutraceutical effect provoked by the antioxidant capacity of Moringa (Prakash, et al., 2007; Ebrahimzadeh, et al., 2009; Ashong \& Brown, 2011). This is supported with the concentration of triglycerides where there are significant differences $(p<0.001)$; when increasing the inclusion of Moringa, this decreases inversely to the concentration of $\mathrm{HDL}$, which indeed increases, presenting significant differences in the study by the inclusion of MOR $(p<0.001)$. Portomicrons (lipoproteins) in birds are transported by via porta vein, and not lymphatic as chylomicrons in mammals. The lipoproteins metabolism, plasma lipids levels, and lipid 
Table 6 - Results of blood chemistry markers of liver and kidney function Japanese quail males with inclusión diets of Moringa $0,7,14$ and $21 \%$, without and with AGP, to $35 \mathrm{~d}$.

\begin{tabular}{|c|c|c|c|c|c|c|c|c|c|}
\hline Ítem & Level & $\begin{array}{c}\text { Uric acid } \\
4.4-10.1 \\
\mathrm{mg} / \mathrm{dL}\end{array}$ & $\begin{array}{l}\text { Cholesterol } \\
<5.3 \mathrm{mmol} / \mathrm{L}\end{array}$ & $\begin{array}{c}\mathrm{LDL} \\
3.90-2.22 \\
\mathrm{mmol} / \mathrm{L} \\
\end{array}$ & $\begin{array}{c}\mathrm{HDL} \\
2.38-3.92 \\
\mathrm{mmol} / \mathrm{L} \\
\end{array}$ & $\begin{array}{c}\text { Triglycerides } \\
<105 \\
\mathrm{mg} / \mathrm{dL} \\
\end{array}$ & $\begin{array}{c}\text { ALT } \\
10.73-16.87 \\
U / L \\
\end{array}$ & $\begin{array}{c}\text { AST } \\
214.88-230.72 \\
U / L \\
\end{array}$ & $\begin{array}{c}\text { Creatinine } \\
0.25-0.35 \\
\mathrm{mg} / \mathrm{dL}\end{array}$ \\
\hline \multicolumn{10}{|l|}{ Main effect } \\
\hline \multirow{4}{*}{ MOR } & 0 & 3.98 & $5.85^{\mathrm{a}}$ & 4.19 & $1.31^{b}$ & $92.90^{a}$ & $16.40^{\mathrm{a}}$ & $228.80^{a}$ & $0.34^{a}$ \\
\hline & 7 & 4.11 & $5.55^{\mathrm{ab}}$ & 3.81 & $2.02^{\mathrm{a}}$ & $89.90^{a}$ & $15.30^{b}$ & $223.80^{b}$ & $0.32^{\mathrm{b}}$ \\
\hline & 14 & 4.09 & $5.33^{\mathrm{ab}}$ & 3.77 & $2.14^{a}$ & $83.40^{b}$ & $14.40^{b c}$ & $220.30^{c}$ & $0.29^{c}$ \\
\hline & 21 & 3.72 & $5.26^{b}$ & 3.73 & $2.23^{a}$ & $77.30^{c}$ & $13.50^{c}$ & $217.50^{d}$ & $0.28^{c}$ \\
\hline SEM $^{1}$ & & 0.17 & 0.14 & 0.16 & 0.06 & 1.40 & 0.245 & 0.530 & 0.01 \\
\hline \multirow{2}{*}{ AGP } & Without & 4.13 & 5.374 & $3.57^{a}$ & 1.95 & 87.05 & 15.10 & $221.75^{b}$ & $0.30^{\mathrm{b}}$ \\
\hline & With & 3.83 & 5.622 & $4.18^{b}$ & 1.9 & 84.70 & 14.70 & $223.45^{\mathrm{a}}$ & $0.32^{\mathrm{a}}$ \\
\hline SEM $^{1}$ & & 0.12 & 0.10 & 0.11 & 0.04 & 0.99 & 0.17 & 0.37 & 0.01 \\
\hline \multicolumn{10}{|l|}{ Interaction effect } \\
\hline 0 & Without & 4.13 & 5.880 & 3.70 & 1.42 & 92.80 & 16.80 & 227.80 & 0.34 \\
\hline 0 & With & 3.83 & 5.812 & 4.68 & 1.19 & 93.00 & 16.00 & 229.80 & 0.34 \\
\hline 7 & Without & 4.12 & 5.306 & 3.50 & 2.01 & 91.60 & 15.40 & 223.20 & 0.31 \\
\hline 7 & With & 4.10 & 5.800 & 4.12 & 2.04 & 88.20 & 15.20 & 224.40 & 0.33 \\
\hline 14 & Without & 3.76 & 5.144 & 3.54 & 2.14 & 84.80 & 14.60 & 219.40 & 0.28 \\
\hline 14 & With & 4.41 & 5.516 & 4.00 & 2.14 & 82.00 & 14.20 & 221.20 & 0.31 \\
\hline 21 & Without & 3.66 & 5.164 & 3.54 & 2.22 & 79.00 & 13.60 & 216.60 & 0.28 \\
\hline 21 & With & 3.78 & 5.360 & 3.92 & 2.24 & 75.60 & 13.40 & 218.40 & 0.29 \\
\hline $\mathrm{SEM}^{2}$ & & 0.24 & 0.20 & 0.22 & 0.08 & 1.97 & 0.346 & 0.750 & 0.01 \\
\hline Source of variation & \multicolumn{9}{|c|}{$p$ value } \\
\hline MOR & & 0.349 & 0.027 & 0.158 & 0.001 & 0.001 & 0.001 & 0.001 & 0.001 \\
\hline AGP & & 0.513 & 0.089 & 0.001 & 0.466 & 0.102 & 0.112 & 0.003 & 0.007 \\
\hline$M O R * A G P$ & & 0.251 & 0.534 & 0.544 & 0.387 & 0.767 & 0.801 & 0.956 & 0.127 \\
\hline
\end{tabular}

a,b,cifferent letters in the lineindicate significant differences between samples $(p \leq 0.05)$.

'Standard error of the means for MOR $(n=10)$ and AGP $(n=20)$.

${ }^{2}$ Standard error of the means for MOR and AGP levels interaction AGP $(n=5)$.

accumulation differs between males and females and between blood or genetic lines, as well as the type of diet and physical activity (Osorio et al., 2011). It is very common that these values increase in commercial birds in cages due to the diet and to their reduced physical activity, especially in quails, that along with this, are of fast growth, being more prone to this condition.

\section{Antimicrobial Activity}

This effect can be seen in the evaluation of the antimicrobial activity of Moringa extracts, soybean meal, and white corn where the only material that had activity was the Moringa extracts. Table 7 shows that the highest inhibition was observed in Gram (+) bacteria, followed by the Gram (-) and fungus. This activity is related to the phenolic compounds and flavonoids present in Moringa (Devendra et al., 2011; Ndhlala et al., 2014). This effect is mainly associated to compounds such as phenolic acids (gallic acid, chlorogenic acid, ferulic acid and ellagic acid) and flavonoids (quercetin and kaemferol) present in Moringa (Prakash et al., 2007; Adaora \& Florett, 2014). Because of this, the nutraceutical and antibacterial effect occurs primarily due to the extracts of Moringa. These effects and the structural requirements are not fully defined for the antimicrobial activity. There are studies that show there must be at least hydroxyl $(-\mathrm{OH})$ and methoxy $\left(-\mathrm{OCH}_{3}\right)$ groups, and some degree of lipophilicity (Modak et al., 2002; Sánchez-Maldonado et al., 2011) as it is the case of phenolic compounds found in Moringa. These groups provoke an oxidative phosphorylation, causing a pH elevation; and therefore, toxicity. Although these groups are in greater proportion in flavonoids, in particular in flavones (Mukne et al., 2011), SánchezMaldonado et al., (2011) found that phenolic acids such as benzoic acid, cinnamic acid, hydroxybenzoic acids ( $p$-hydroxybenzoic, protocatechuic, gallic and syringic) and hydroxycinnamic acids (p-coumaric, caffeic and ferulic), the antimicrobial activity of hydroxycinnamic acids was comparable or greater than the hydroxybenzoic acids with the same number of hydroxyl groups. The greater number of hydroxyl groups polyphenolic compounds there are, the more efficient uncoupling compounds they become, transferring more protons per molecule (Omojate et al., 2014), raising their level of lipophilicity (Modak et 
Castillo LR, Portillo UJ, León FJ, Gutiérrez DR, Angulo EMA, Muy-Rangel MD, Heredia JB

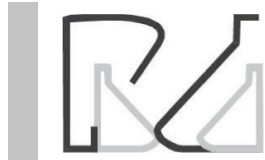

Inclusion of Moringa Leaf Powder (Moringa oleifera) in Fodder for Feeding Japanese Quail (Coturnix coturnix japonica)

Table 7 - Antimicrobial activity by the halo of inhibition of the major components of the diet.

\begin{tabular}{|c|c|c|c|c|c|c|}
\hline Methanol Extract ${ }^{1}$ & $\begin{array}{c}\text { Staphilococus } \\
\text { aeureus }\end{array}$ & Salmonella & Escherichia coli & Candida albicans & $\begin{array}{c}\text { Pseudomona } \\
\text { aeuginosa }\end{array}$ & $\begin{array}{c}\text { Listeria } \\
\text { monocytogenes }\end{array}$ \\
\hline Moringa & $22.54 \pm 1.24$ & $17.03 \pm 0.71$ & $12.42 \pm 0.47$ & $14.36 \pm 0.45$ & $14.81 \pm 0.68$ & $23.63 \pm 0.96$ \\
\hline Soybean & - & - & - & - & - & - \\
\hline White maize & - & - & - & - & - & - \\
\hline Ampicillin (Control) & $31.41 \pm 0.85$ & $26.51 \pm 0.55$ & $15.01 \pm 0.39$ & $14.36 \pm 0.33$ & $16.21 \pm 0.62$ & $30.16 \pm 0.47$ \\
\hline $\mathrm{MeOH}(80 \%)$ & - & - & - & - & - & - \\
\hline
\end{tabular}

Units in $\mathrm{mm}$ (Mean \pm SEM), SEM:Standard error of the means.

${ }^{1}$ Analyzed in triplicate samples.

al., 2002; Mukne et al., 2011). This effect is due to the high grade of hydrophobicity or lipid solubility, allowing with this, the separation of the lipidic structure of the membrane cell and mitochondria, messing its structure which causes its permeability, letting the migration of ions and another compounds to happen, resulting in an imbalance homeostatic (Rosas-Gallo \& Lopez-Malo, 2011); and therefore, exercising a cytotoxic effect in the cells (García-García \& Paulo-Garcia, 2008).

\section{CONCLUSION}

The results of this experiment showed that flour from leaves of Moringa oleifera is a viable alternative to be included up to $14 \%$ in commercial diets of birds offering an option for AGP replacement without compromising the health of the animal and therefore its productivity.

\section{ACKNOWLEDGMENT}

We gratefully acknowledge to Laura Contreras, Celida Martínez, Olimpia Soto, Omar Camacho, Guadalupe Estrada, Carlos Bell Castro and Vladimir Martinez for their help and excellent technical support. Also to Joel Palazuelos for his proof reading of this manuscript. Authors would also like to thank CONACYT-México for the scholarship granted.

\section{BIBLIOGRAPHY}

Aami AM, Kermanshahi H, Golian, A. The effect of dietary energy and protein levels on growth performance and antibody responses of offspring of laying japanese quails. Iranian Journal of Applied Animal Science 2014;4(1):185-190.

Adline J, Devi A. A study on phytochemical screening and antibacterial activity of Moringa oleifera. International Journal of Research in Applied. Natural and Social Sciences 2014;2(5):169-176

Ajayi AO, Fadeyi TE. Antimicrobial activities and phytochemical analysis of Moringa oleifera leaves on Staphylococus aureus and Streptococcus species. American Journal of Phytomedicine and Clinical Therapeutics 2015;3(10):643-653.

Aletor VA, Egberongbe O. Feeding differently processed soya bean part 2. An assessment of haematological responses in the chicken. Food Nahrung 1992;36(4):364-369.
Amer MY, Khan SH. A comparison between the effects of a probiotic and an antibiotic on the performance of Desi chickens. Veterinary World 2012;5(3):160-165.

AOAC. Official methods of analysis. $17^{\text {th }}$ ed. Washington: Association of Official Analytical Chemists; 2000.

AOAC. Official Methods of Analysis. $18^{\text {th }}$ ed. Association of Official Analytical Chemists, Gaithersburg: AOAC International; 2005.

AOAC. Official Methods of Analysis. $16^{\text {th }}$ ed. Washington: Association of Official Analytical Chemists; 1998.

Ashong JO, Brown DL. Safety and efficacy of Moringa oleifera powder for growing poultry. Journal of Animal Science 2011;1:89:84.

Asrani RK, Katoch RC, Gupta VK, Deshmukh S, Jindal N, Ledoux DR, et al. Effects of feeding Fusarium verticillioides (formerly Fusarium moniliforme) culture material containing known levels of fumonisin B1 in Japanese quail (Coturnix coturnix japonica). Poultry Science 2006;85(7):1129-1135.

Ayasan T. Effects of dietary inclusion of protexin (probiotic) on hatchability of Japanese quails. Indian Journal of Animal Sciences 2013;83(1):7881.

Ayasan T. Use of Moringa oleifera in poultry and ruminant nutrition. Turkish Journal Of Agriculture - Food Science and Technology 2015;3(6):425429 .

Aybar M. La codorniz: crianza y explotación [disertación]. Ica (PE): Universidad San Juan Bautista; 2011. Availabre from: http:// es.slideshare.net/CSSMAV/la-codorniz-monografia-aybar-valencia.

Ayoola AA, Egbeyale LT, Sogunle OM, Ekunseitan DA, Adeyemi AA. Effects of age and sex on haematological and serum biochemistry in Japanese quails. Animal Health and Production 2015;63(1):43-21.

Brizuela MA, Serrano P, Almazán O, Rodríguez JA, Camps DM, Bueno G, et al. Probiotics and enzymes. A natural alternative to antibiotics use. ICIDCA Sobre los Derivados de la Caña de Azúcar 2009;43(2):30-36.

Cruz VC, Pezzato AC, Pinheiro DF, Goncalves JC, Sartori JR. Effect of freechoice feeding on the performance and ileal digestibility of nutrients in broilers. Revista Brasileira de Ciência Avícola 2005;7(3):143-150.

Devendra BN, Srinivas N, Prasad VSSL, Latha PS. Antimicrobial activity of Moringa oleifera lam., leaf extract, against selected bacterial and fungal strains. International Journal of Pharma and Bio Sciences 2011;2(3):B13-8.

Dibner JJ, Richards JD. Antibiotic growth promoters in agriculture: history and mode of action. Poultry Science 2005;84(4):634-643.

Ebrahimzadeh MA, Ghasemi K, Ghasemi Y. Antioxidant activity, phenol and flavonoid contents of 13 citrus species peels and tissues. Pakistan Journal of Pharmaceutical Sciences 2009;22(3):277-281.

Fahey JW. Moringa oleifera: A review of the medical evidence for its nutritional, therapeutic, and prophylactic properties. Part 1. Trees for Life Journal 2005;1(5):1-15. Available from: http://www.TFLjournal. org/article.php/20051201124931586. 
Castillo LR, Portillo UJ, León FJ,

Gutiérrez DR, Angulo EMA,

Muy-Rangel MD, Heredia JB

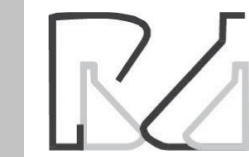

Inclusion of Moringa Leaf Powder (Moringa oleifera) in Fodder for Feeding Japanese Quail (Coturnix coturnix japonica)
Folch J, Lees M, Sloane-Stanley GH. A simple method for isolation and purification of total lipids from animal tissues. Journal of Biological Chemistry 1957;226(1):497-509.

Gadzirayi CT, Masamha B, Mupangwa JF, Washaya S. Performance of broiler chickens fed on mature Moringa oleifera leaf meal as a protein supplement to soyabean meal. International Journal of Poultry Science 2012;11(1):5-10

García-García RM, Palou-García E. Mecanismos de acción antimicrobiana de timol y carvacrol sobre microorganismos de interés en alimentos. Temas selectivos de Ingeniería de Alimentos 2008;2(2):41-51.

Gauthier R, Bodin JC, Fernández-Oller A. Alternativa a los antibióticos promotores de crecimiento para pollos. Selecciones Avícolas 2011;53(12):19-23.

Genchev A, Mihaylov R. Slaughter analysis protocol in experiments using Japanese quails (Coturnix Japonica). Trakia Journal of Sciences 2008;6(4):66-71.

Itoh N, Makita T, Koiwa M. Characteristics of blood chemical parameters in male and female quails. Journal of Veterinary Medical Science 1998;60(9):1035-1037

Lucotte, G. Cría de los pollos de codorniz. La Codorniz: cría y explotación. $2^{\text {nd }}$ ed. Madrid: Mundi-Prensa; 1990.

Makkar HPS, Becker K. Nutrional value and antinutritional components of whole and ethanol extracted Moringa oleifera leaves. Animal Feed Science And Technology 1996;63(1):211-228.

Mateos, GG, Jiménez-Moreno E, Serrano MP, Lázaro RP. Poultry response to high levels of dietary fiber sources varying in physical and chemical characteristics. The Journal of Applied Poultry Research 2012;21(1):156174.

Mexican. NOM-033-ZOO-2014. Methods for give death to domestic and wild animals. Diario Oficial de la Federación, México DF, México; 2014.

Mexican. NOM-062-ZOO-1999. Technical specifications for the production, care and use of laboratory animals. Diario Oficial de la Federación, México DF, México;1995.

Modak B, Arrieta A, Torres R, Urzua A. Actividad antibacteriana de flavonoides aislados del exudado resinoso de Heliotropium sinuatum: efecto del tipo de estructura. Boletín de la Sociedad Chilena de Química 2002;47(1):19-23.

Moir KW, Yule WJ, Connor JK. Energy losses in the excreta of poultry: a model for predicting dietary metabolizable energy. Animal Production Science 1980;20(103):151-155.

Mukne AP, Viswanathan $V$, Phadatare AG. Structure pre-requisites for isoflavones as effective antibacterial agents. Pharmacognosy Reviews 2011;5(9):13-18

NRC - National Research Council. Nutrient requirements of poultry. $9^{\text {th }}$ ed. Washington: National Academy of Sciences; 1994.

Ndhlala AR, Mulaudzi R, Ncube B, Abdelgadir HA, Du-Plooy, CP, Van-Staden J. Antioxidant, antimicrobial and phytochemical variations in thirteen Moringa oleifera Lam. Cultivars. Molecules 2014;19(7):10480-10494.

Obregón JF, Bell C, Elenes I, Estrada A, Portillo JJ, Ríos FG. Efecto de la cocción de garbanzo (Cicer arietinum L.) de descarte en la respuesta productiva y rendimiento en canal de la codorniz japonesa en engorde (Coturnix coturnix japonica). Revista Cubana de Ciencia Agrícola 2012:46(2):169-173.

Okorondu SI, Akujobi CO, Okorondu JN, Anyado-Nwadike SO. Antimicrobial activity of the leaf extracts of Moringa oleifera and Jatropha curcas on pathogenic bacteria. International Journal of Biological and Chemical Sciences 2013;7(1):195-202.

Olugbemi TS, Mutayoba SK, Lekule FP. Effect of Moringa (Moringa oleifera) inclusion in cassava based diets fed to broiler chickens. International Journal of Poultry Science 2010;9(4):363-367.
Omojate-Godstime C, Enwa-Felix O, Jewo-Augustina O, Eze-Christopher $\mathrm{O}$. Mechanisms of antimicrobial actions of phytochemicals against enteric pathogens-a review. Journal of Pharmaceutical, Chemical and Biological Sciences 2014;2(2):77-85.

Onibi GE, Bobadoye AO, Folorunso OR. Haematological indices, serum cholesterol and meat quality of broiler chikens fed diets with palm oil sluge substituting maize. Agriculture and Biology Journal of North America 2011:2:552-558

Osorio JH, Flórez JD. Diferencias bioquímicas y fisiológicas en el metabolismo de lipoproteínas de aves comerciales. Biosalud 2011;10(1):88-98.

Ponce AG, Fritz R, Del Valle C, Roura SI. Antimicrobial activity of essential oils on the native microflora of organic Swiss chard. LWT-Food Science and Technology 2003;36(7):679-684.

Prabuseenivasan S, Jayakumar $\mathrm{M}$, Ignacimuthu S. In vitro antibacterial activity of some plant essential oils. BMC Complementary and Alternative Medicine2006;6(1):1-8

Prakash D, Suri S, Upadhyay G, Singh BN. Total phenol, antioxidant and free radical scavenging activities of some medicinal plants. International Journal of Food Sciences and Nutrition 2007;58(1):18-28.

Ramírez LAG, Montoya OI, Zea JMV. Probióticos: una alternativa de producción limpia y de remplazo a los antibióticos promotores de crecimiento en la alimentación animal. Producción + Limpia 2013;8(1):135-146

Reece RL. Review of adverse effects of chemotherapeutic agents in poultry. World's Poultry Science Journal 1988;44(3):193-216.

Rosas-Gallo A, López-Malo A. Actividad antimicrobiana de aceite esencial de tomillo (Thymus vulgaris). Temas Selectos de Ingeniería de Alimentos 2011;5(1):41-50.

Saikia LR, Upadhyaya S. Antioxidant activity, phenol and flavonoid content of some less known medicinal plants of Assam. International Journal of Pharma and Bio Sciences 2011;2:383-388.

Sánchez Maldonado AF, Schieber A, Gänzle MG. Structure-function relationships of the antibacterial activity of phenolic acids and their metabolism by lactic acid bacteria. Journal of Applied Microbiology 2011;111(5):1176-1184.

Sankhalkar S. Antioxidant enzyme activity, phenolics and flavonoid content in vegetative and reproductive parts of Moringa oleifera Lam. American Journal of PharmTech Research 2014;4:255-270.

Sell JL.Physiological limitations and potential for improvement in gastrointestinal tract function of poultry. The Journal of Applied Poultry Research 1996;5(1):96-101

Singh BN, Singh BR, Singh RL, Prakash D, Dhakarey R, Upadhyay G, et al. Oxidative DNA damage protective activity, antioxidant and antiquorum sensing potentials of Moringa oleifera. Food and Chemical Toxicology 2009;47(6):1109-1116.

Uyanik F, Eren M, Güçlü BK, Şahin N. Effects of dietary chromium supplementation on performance, carcass traits, serum metabolites, and tissue chromium levels of Japanese quails. Biological Trace Element Research 2005:103(2):187-197.

Vázquez-Ortiz FA, Caire G, Higuera-Ciapara I, Hernández G. High performance liquid chromatographic determination of free amino acids in shrimp. Journal of Liquid Chromatography \& Related Technologies 1995;18(10):2059-2068.

Woodard AE, Abplanalp H, Wilson WO. Japanese quail husbandry in the laboratory (Coturnix coturnix japónica). Davis: Department of Avian Sciences, University of California; 1973. 